NOTA CIENTÍFICA

Effects of aqueous extract of Origanum vulgare L. (Lamiaceae) on the preimplantational mouse embryos

\title{
Efecto del extracto acuoso de Origanum vulgare L. (Lamiaceae) en embrio- nes preimplantacionales de ratón
}

\author{
Víctor Benavides*, Guadalupe D’Arrigo and José Pino
}

\begin{abstract}
Laboratorio de Reproducción y Biología de Desarrollo. Facultad de Ciencias Biológicas. Universidad Nacional Mayor de San Marcos, Ciudad Universitaria, Av. Venezuela s/n. Apartado postal 11-058, Lima 11

Email Victor Benavides: vbenavides23@hotmail.com * Dirección para correspondencias: Jr. Lazareto 398, Urb. Miguel Grau, Lima31, Lima - Perú.
\end{abstract}

$\begin{array}{ll}\text { Presentado: } & 17 / 06 / 2010 \\ \text { Aceptado: } & 15 / 12 / 2010\end{array}$ $\begin{array}{ll}\text { Aceptado: } & 15 / 12 / 2010 \\ \text { Publicado online: } & 21 / 01 / 2011\end{array}$

\begin{abstract}
The use of medicinal plants for the treatment of illnesses is widely known. However, there are not many scientific reports about the properties of these plants and their side effects. In this study, the effect of the aqueous extract of Origanum vulgare on the preimplantational mouse embryo development was investigated. The oregano aqueous extract was given ad libitum to four separated groups $(n=10)$ of pregnant mice: $0,9,18$ y $36 \mathrm{mg} / \mathrm{mL}$ respectively. When the embryos were evaluated, a slight delay in the embryo development was observed, but only with the highest dose. With respect to embryo quality, an increase of degenerated embryos was observed but this was not significant. These results showed that the aqueous extract of $O$. vulgare does not have a toxic effect on preimplantational mouse embryo, and it only produces a slight delay in embryo development.
\end{abstract}

Key words: Preimplantational embryo, Traditional Medicine, Origanum vulgare, embryotoxicity.

\section{Resumen}

El uso de las plantas medicinales para el tratamiento de las enfermedades es ampliamente conocido. Sin embargo, no hay muchos informes científicos sobre las propiedades de dichas plantas y sus efectos secundarios. En este estudio, se ha investigado el efecto del extracto acuoso de Origanum vulgare en el desarrollo preimplantacional de embriones de ratón. El extracto acuoso fue administrado (0, 9, 18 y $36 \mathrm{mg} / \mathrm{mL})$ : vía oral; ad libitum, respectivamente a cuatro grupos de ratonas preñadas $(n=10)$. Cuando los embriones fueron evaluados sólamente con la dosis más alta se observó un ligero retraso en el desarrollo del embrión. Con respecto a la calidad del embrión, se evidencio un aumento de embriones degenerados, pero esto no fue significativo. Estos resultados mostraron que el extracto acuoso de 0 . vulgare no tiene un efecto tóxico en embriones de ratón preimplantacional, y sólo produce un ligero retraso en el desarrollo del embrión.

Palabras clave: Embrión preimplantacional, Medicina tradicional, Origanum vulgare, embriotoxicidad.

\section{Introduction}

Of the 250,000 species of flowering plants in the World, more than 20,000 - nearly $10 \%$ of the total - are classified as herbs. Herbs picked by people from the wild have been an essential factor in health care all over the World throughout the ages and in all cultures. Nowadays, some $80 \%$ of the World's people rely on traditional, plant-based medicines for their primary health care (Cosge et al. 2009).

Actually, there exists a tendency to use natural products for the treatment of several illnesses. With use of medicinal plants, investigations have been performed all over the world in order to find more productive and economical medicines (Goze et al. 2010). Medications used to cure disorders require continuous changing to improve their effectiveness. However, few of the many claims of therapeutic efficacy have been validated adequately by clinical trials; Even though these claims have been substantiated scientifically, complementary medicines are unlikely to secure a place in conventional healthcare (Hammer et al. 1998).

The Labiatae family (Lamiaceae) is one of the largest and most distinctive families of flowering plants, with about 220 genera and almost 4000 species worldwide (Naghibi et al. 2005); Labiatae are best known for the essential oils common to many members of the family (Jones 1996, cited by Hammer et al. 1999). O. vulgare "oregano" is a herb widely used in cooking and natural medicine (Fon Quer 1985, Naghibi et al. 2005) that include many effective antioxidants, such as Rosmarinic acid, caffeic acid and various flavonoids (Yoshino et al. 2006).
In a study on the phenolic acids recovered in human urine after single ingestion of Origanum onites extract, Nurmi et al. (2006) identified phenolic constituent in the extract was rosmarinic acid, representing $75 \%$ of the identified phenolic acids. Other phenolic acids, including protocatechuic acid, $p$-coumaric acid, ferulic acid, chlorogenic acid and gallic acid, were present in the extract in notably lower amounts. The extract also contained minor amounts of the flavonoids luteolin and eriodictyol. In scientific reports about the medicinal properties of oregano: Origanum oil, mainly rich in carvacrol (Bakkali et al. 2008), is used as a painkiller in rheumatism by rubbing externally on painful limbs. The aromatic oregano water, rich in carvacrol, is consumed to check gastrointestinal disorders, reduce blood cholesterol and glucose level and also for tumor suppressive activities (Goze et al. 2010); against whooping and convulsive coughs, digestive disorders and menstrual problems (Gurudatt et al. 2010), also its calming (Lans et al. 2007), antimicrobial (Nazia et al. 2007) and antifungal activity is emphasized (Hammer et al. 1998, 1999; Ultee et al. 1999). In Northern Peru, leaves and stems, fresh or dried, of oregano are employed as traditional remedies for menstrual cramps, menstruation and lower stomach cramps related to premenstrual stages (Bussmann \& Glenn 2010).

It is known that during the early pregnancy, the mammal embryo is susceptible to the toxic action of some drugs. These harmful effects depend on the exposure time and its concentration. At the undifferentiated stage of zygote proliferation and before implantation, exposure to a teratogen usually either kills 
the fertilized ovum which results in a spontaneous abortion, or spares it completely (Stanley \& Bower 1986). During the recent years there have been reports on the toxic effects of some medicinal plants on the mouse embryo development (Lemonica et al. 1996, Gutierrez-Pajares et al. 2003). Although it is common to evaluate xenobiotic effects on mammalian embryos during organogenesis, the effects of these agents on preimplantation development is less commonly studied. Toxic agents or an unfavorable environment during preimplantation stages could alter normal events to arrest embryos or invoke abnormalities that affect subsequent stages of development. In a previous work, Benavides et al. (2000) found $10 \%$ of abnormal embryos when $20 \%$ aqueous extract of oregano was orally provided to pregnant mice in contrast to $14,29 \%$ of abnormal embryos found in the control group.

For this reason, it is necessary to evaluate and rule out the possible side or toxic effects that those plants could have (Benavides el al. 2001). The aim of this study was to examine the possible embryotoxicity of aqueous extract of $O$. vulgare on the mouse preimplantational embryo development.

\section{Material and methods}

Botanical samples were obtained from marketplace suppliers who had collected the plants from public lands. They were identi-
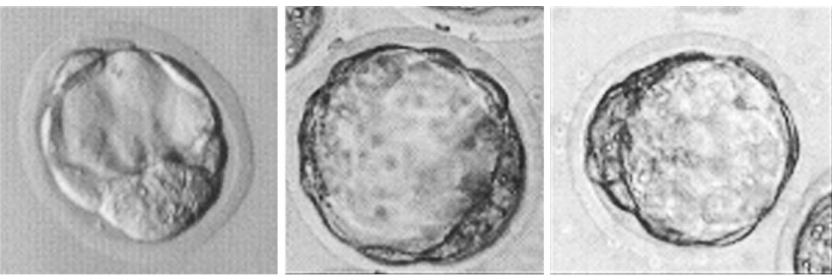

GRADE 1
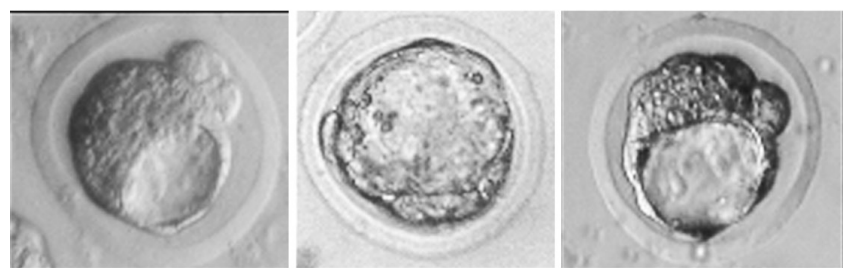

GRADE 2
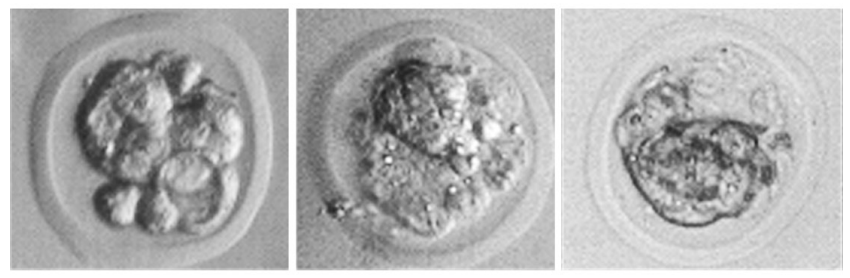

GRADE 3
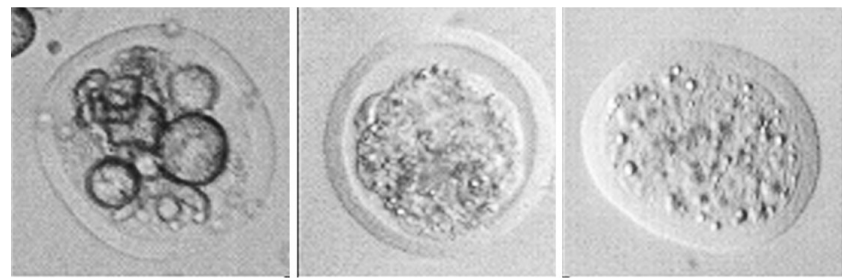

Degenerated

Figure 1. Gradation of $96 \mathrm{hpc}$ preimplantational embryos. fied by Esther Cox, professor of Facultad de Ciencias Biológicas, Universidad Nacional Mayor de San Marcos. Voucher specimens of species studied are deposited in our laboratory.

Swiss Rockefeller strain mice from our animal house were maintained with a photoperiod of $14 \mathrm{~h}$ light $/ 10 \mathrm{~h}$ dark, $22-24$ ${ }^{\circ} \mathrm{C}$ room temperature and free access to balanced diet pellets (Purina, Peru). Females between six to eight weeks old were mated with proved fertile males between $8-12$ weeks old. When a vaginal plug was observed, it was considered to be day one of pregnancy.

Aqueous extract.- Leaves of $O$. vulgare were dried at $60^{\circ} \mathrm{C}$ in a stove for $24 \mathrm{~h}$. The aqueous extract was prepared heating $300 \mathrm{~g}$ of oregano in $1500 \mathrm{~mL}$ of distillated water at $60{ }^{\circ} \mathrm{C}$ for 15 minutes, and then the extract was decanted. After filtration, a sample was separated for determination of the solid concentration $(36 \mathrm{mg} / \mathrm{mL})$. From this extract we prepared doses of $\mathrm{O}$, 9, 18 and $36 \mathrm{mg} / \mathrm{mL}$.

Experimental procedure.- Pregnant females were randomly assigned to four experimental groups: Group Control, Group A, Group B and Group C, each group $(n=10)$ was orally treated with $0,9,18$ and $36 \mathrm{mg} / \mathrm{mL}$ ad libitum of aqueous extract of oregano, respectively since day one to day four. Female mice were euthanized by cervical dislocation 96 hours post copula (h.p.c.) and oviducts and uterine horns were excised, preimplantational embryos were collected by flushing oviducts and uterine horns with phosphate buffer saline (PBS, Sigma) $\mathrm{pH}$ 7,4 supplemented with $4 \mathrm{~g} / \mathrm{L}$ bovine serum albumin (BSA. Sigma Chemical Co.) (Hogan et al. 1986).

Evaluation of embryo morphology and transport.- The stage and embryo quality were evaluated under a phase contrast microscopy and the grade of viability was determined by doing a morphological evaluation following Dorn \& Kramer (1987) protocol with some of our own modifications (Figure 1):

Grade 1: there are no extruded blastomeres and the embryo has a rounded appearance.

Grade 2: there are extruded blastomeres and the embryo may not have a rounded appearance.

Grade 3: there are several extruded blastomeres and the embryo may be extremely malformed.

Degenerated: The embryo may be flat or bowl shape and most of the membranes are broken down.

Statistical analysis.- Data was evaluated by chi-square or Fisher test and all results with $\mathrm{p}<0,05$ were considered statistically significant.

\section{Results}

This is not the first time that our laboratory demonstrated that oral administration of an aqueous extract of an herb causes damage to preimplantation mouse embryos (Gutierrez-Pajares 2003, Gonzales et al. 2007). In this time, this effect is not related to a systemic toxicity since there was no sign of intoxication in any of the doses in the pregnant mice.

Table 1 and 2 show the effects of treatment with aqueous extract of oregano on the early development stages of mouse embryo. Groups A and B did not show a significant difference when they were compared with the group control. There was 
Table 1. Number and percentage of embryos by stage obtained from females treated with aqueous extract of oregano.

\begin{tabular}{cccc}
\hline & 1-8 cells & Morulae & Blastocysts \\
\hline Control & $13,93(11)$ & $29,11(23)$ & $56,96(45)$ \\
Group A & $12,35(10)$ & $19,75(16)$ & $67,9(55)$ \\
Group B & $9,72(7)$ & $34,72(25)$ & $55,56(40)$ \\
Group C & $6,76(5)$ & $51,35(38)^{*}$ & $41,89(31)^{*}$ \\
\hline
\end{tabular}

Numbers in parenthesis represent quantity of evaluated embryos. Asterisks designate significant differences between the control and treated groups ( $p<0,05)$.

not a similar results in group $\mathrm{C}$ where blastocyst stage decreased; $41,89 \%$ in comparison with the control, where it was $56,46 \%$ $(p<0,05)$. A significant increase in the morulae stage was observed in the same group, demonstrating a slight delay in embryo development with the highest dose.

When the embryo quality was examined, we found a significant increase in the occurrence of degenerated embryos in all treated groups in comparison with group control (group A: $13,6 \%$, group B: $9,72 \%$, group C: $13,51 \%$ and group control: $5,06 \%$ ). Also, a significant increase in the number of grade 1 embryos was observed in group B 65, 28\% in comparison with group control 46,84\%. A significant decrease in grade 2 embryos in groups $\mathrm{A}$ and $\mathrm{B}$ was observed. In the same way there was a significant decrease in grade 3 embryos in group C (Table 2).

\section{Discussion}

Domaracký et al. (2007) did not found influence of essential oil of $O$. vulgare (carvacrol, $65 \%$ ) on mouse preimplantational in vivo, however, the embryos was altered only minimally and appeared as an increase of cell death. In our results, there was a significant decrease in grade 3 embryos in group C (Table 2) as well. There are not many scientific reports about toxic activity of $O$. vulgare. Many studies exist in which antimicrobial activity from $O$. vulgare is confirmed. However plants oils and extracts are to be used for food preservation or medicinal purposes, issues of safety and toxicity will need to be addressed (Hammer et al. 1999). It has been reported that $O$. vulgare contains substances that have progestin bioactivity (Zava et al. 1998, Arcila-Lozano 2004), these substances have an action similar to progesterone, and they could act in favor of normal embryo development, which is evidenced by the increase of grade 1 embryos in all treated group, although this increase is only significative in group B. Furthermore, there are reports that $O$. vulgare has antioxidant effects (Yoshino et al. 2006, Jaloszyńsky et al. 2008) in front to the DPPH action, this effect is attributed to the rosmarinic acid (Yoshino et al. 2006) and its derivatives presents in this plant, conferring to $O$. vulgare a protecting character against cell damage by oxidation (Lamaison et al. 1990) or reducing the expression of the proinflammatory gene cyclooxygenase- 2 (COX-2), which has been regarded as a risk factor in tumor development (Scheckel et al. 2008). Arcila-Lozano (2004) affirm that the essential oil from Origanum have the property to increase the activity of the detoxicant enzyme, glutation S-transferase when it is administered orally.

In conclusion; this study shows that aqueous extract of $O$. vulgare does not have a toxic effects on development and morphology of preimplantational mouse embryo; only with the highest dose, a significant delay in the formation of blastocysts was observed.

\section{Literature cited}

Arcila-Lozano C., Loarca-Piña G., Lecona-Uribe S., et al. 2004. El Orégano: Propiedades, Composición y Actividad Biológica de sus Componentes. Archivos Latinoamericanos de Nutrición 54(1): 100-111.

Bakkali F., Averbeck S., Averbeck C. \& M. Idaomar. 2008. Biological effects of essential oils - A Review. Food and Chemical Toxicology 46 (2): 446-475.

Benavides V., D-Arrigo O \& J. Pino. 2001. Efectos Embriotóxicos de Picrosia longifolia Don (ASTERACEAE). Revista Peruana de Biología 8 (1): 80-82.

Benavides, V., Trujillo, G., D'Arrigo, G., et al. 2000. Evaluación toxicológica preliminar de Ruta graveolens, Origanun vulgare y Persea americana sobre embriones preimplantacionales de ratón. Revista Peruana de Biología 7(1): 87-89.

Bussmann R.W. \& A. Glenn. 2010. Medicinal plants used in Northern Peru for reproductive problems and female health. Journal of Ethnobiology and Ethnomedicine 6: 30-30.

Cosge B., A. Turker, I. Ipek, et al. 2009. Chemical compositions and antibacterial activities of the essential oils from aerial parts and corollas of Origanum acutidens (Hand.-Mazz.) Ietswaart, an endemic species to Turkey. Molecules 14:1702-1712.

Domaracký M., P. Rehák, Š. Juhás \& J. Koppel. 2007. Effects of selected plant essential oils on the growth and development of mouse preimplantation embryos in vivo. Physiol. Res. 56: $97-104$.

Dorn C.G. \& D.C. Kramer. 1987. Bovino Embryo Grading. Texas A \& E University, USA.

Font Quer P. (1985). Plantas Medicinales. Editorial Labor S.A. I" edición. Barcelona, España.

Gonzáles J., V. Benavides, R. Rojas \& J. Pino. 2007. Efecto embriotóxico y teratogénico de Ruta chalepensis L. "ruda" en ratón (Mus musculus). Revista Peruana de Biología (Número especial) 13(3):223-225.

Goze I., A. Cetin \& A. Goze. 2010. Investigation of effects of essential oils of Origanum minutiflorum O Schwarz PH Davis and Cyclotrichium niveum (Labiatae) plants on angiogenesis in shell-less Chick embryo culture. African Journal of Biotechnology 9(14): 2156-2160.

Gurudatt P., V. Priti, S. Shweta, et al. 2010. Changes in the essential oil content and composition of Origanum vulgare L. during annual growth from Kumaon Himalaya. Current Science 98 (8):1010- 1012.

Gutierrez-Pajares J.L., Zúñiga L. \& J. Pino. 2003. Ruta graveolens aqueous extract retards mouse preimplantation embryo development. Reproductive Toxicology 17(6): 667-672.

Table 2. Number and percentage of embryo quality obtained from females treated with aqueous extract of oregano. Control vs. treated groups.

\begin{tabular}{ccccc}
\hline & Grade 1 & Grade 2 & Grade 3 & Degenerate \\
\hline Control & $46,84(37)$ & $32,91(26)$ & $15,19(12)$ & $5,06(4)$ \\
Group A & $61,73(50)$ & $17,28(14)^{*}$ & $7,41(6)$ & $13,58(11)$ \\
Group B & $65,28(47)^{*}$ & $13,69(10)^{*}$ & $11,11(8)$ & $9,72(7)$ \\
Group C & $51,35(38)$ & $32,43(24)$ & $2,70(2)^{*}$ & $13,51(10)$ \\
\hline
\end{tabular}

Numbers in parenthesis represent quantity of evaluated embryos. Asterisks designate significant differences between the control and treated groups $(* \mathrm{p}<0.05)$. 
Hammer K.A., Carson C.F. \& T.V. Rilley. 1998. In-vitro activity of essential oils in particular Melaleuca allemifolia (tea tree) oil and tea tree oil products, against Candida spp. Journal of Antimicrobial Chemotherapy 42: 591-595.

Hammer K.A., C.F. Carson \& T.V. Rilley. 1999. Antimicrobial activity of essential oils and other plant extracted. Journal of Applied Microbiology 86:985-599.

Hogan B., F. Constantini \& E. Lacy. 1986. Manipulating the mouse embryo. A Laboratory Manual. USA Cold Spring Harbor Laboratory.

Jaloszyńsky K., A. Figiel \& A. Wojdylo. 2008. Drying kinetics and antioxidant activity of oregano. Acta Agrophysica 11 (1): $81-90$

Lamaison J., C. Petitjean-Freytget \& A. Carnat. 1990. Rosmarinic acid, total hydroxycinnamic derivates and antioxidant activity of Apiaceae borraginaceae and Lamiaceae medicinais. Annales Pharmaceutiques Françaises 48:103-8.

Lans C., N. Turner, T. Khan, et al. 2007. Ethno veterinary medicines used for ruminants in British Columbia, Canada. Journal of Ethnobiology and Ethnomedicine. 3:11.

Lemonica I.P, D.C. Damasceno \& L.C. Di-Stací. 1996. Study of the embryotoxic effects of an extract of Roseniary (Rosmarinas officinalis L.). Brazilian Journal of Medical and Biological Research 29: 223-227.

Naghibi F., M. Mosaddegh, S. Mohammadi \& A. Ghorbani. 2005. Labiatae Family in folk Medicine in Iran: from Ethnobotany to Pharmacology. Iranian Journal of Pharmaceutical Research 2: 63-79.
Nazia A., S. Sabahat \& T. Perween. 2007. Antibacterial effects of Oregano (Origanum vulgare) against Gram Negative Bacilli. Pakistan Journal of Botany. 39(2): 609-613.

Nurmi A., T. Nurmi, J. Mursu, et al. 2006. Ingestion of Oregano Extract Increases Excretion of Urinary Phenolic Metabolites in Humans. J. Agric. Food Chem. 54: 6916-6923.

Scheckel K., S. Degner \& R. Romagnolo. 2008. Rosmarinic Acid Antagonizes Activator Protein-1-Dependent Activation of Cyclooxygenase-2 Expression in Human Cancer and Nonmalignant Cell Lines. The Journal of Nutrition 138: 2098-2105.

Stanley F. \& C. Bower. 1986. Teratogenic drugs in pregnancy. Medicine Journal of Australia. 145: 596- 599.

Ultee A, E. Kets \& E. Smid. 1999. Mechanisms of action of Carvacrol on me food-bome pathogen Bacillus cereus. Applied Environmental Microbiology. 65:4606-4610.

Yoshino K., N. Higashi \& K. Koga. 2006. Antioxidant and Antiinflammatory Activities of Oregano Extract. Journal of Health Science 52(2): 169-173.

Zava D.T., C.M. Dollbaum \& M. Blen. 1998. Estrogen and progestin bioactivity of foods, herbs and spices. Proceeding Society Experimental Biology Medicine 217:369-78. 